\title{
Hyalinized Stroma Formation
}

National Cancer Institute

\section{Source}

National Cancer Institute. Hyalinized Stroma Formation. NCI Thesaurus. Code C36000.

Replacement of tissue stromal elements by hyaline material. 